\title{
Influence of polymer coating on seed and seedling quality characteristics
}

\author{
N. Suma, P. Srimathi. \\ Department of Seed Science and Technology, Tamilnadu Agricultural University, Coimbatore-6
}

\begin{abstract}
The present study on polymer coating revealed that the seed coated with polymer @ $4 \mathrm{~g} \mathrm{~kg}^{-1}$ seed has increased the germination to 89 per cent followed by seeds coated with polymer @ $3 \mathrm{~g} \mathrm{~kg}^{-1}$ seed (87 per cent).The other parameters like root length, shoot length, drymatter production and vigour index were also higher in seeds coated with polymer @ $4 \mathrm{~g} \mathrm{~kg}^{-1}$ seed.

Keywords: polymer,coating, sesame, quality characteristics.
\end{abstract}

\section{Introduction}

Seeds also require seed treatment for enclosing the protective chemicals, and nutrients added to the seeds without significant increase the seed size or weight without the loss of chemicals, which can be achieved by polymer coating. Polymer coating enables accurate and even dosage of chemicals and reduces the chemical wastage. Kumar et al. (1992) also expressed that mustard seeds could be coated with 1.5 per cent Jalashakthi for maximized productivity which was also supported by Wadhwa et al. (1989) in sunflower and Bharambe et al. (1993) in groundnut.

\section{Materials And Methods}

Genetically pure seeds of sesamum (Sesamum indium.) cv. CO1 obtained from Department of oilseeds, TNAU, Coimbatore, formed the base material for the study. The field experiments and laboratory experiments were conducted at Department of Seed Science and Technology, Tamil Nadu Agricultural University, Coimbatore $\left(11^{\circ} \mathrm{N}\right.$ latitude and $77^{\circ} \mathrm{E}$ longitude with an altitude of $427 \mathrm{~m}$ above mean sea level) during 2004-2005.

\section{Standardization of dose of polymer for seed coating.}

The fresh seeds were coated with black polymer, @ 3,4 and $5 \mathrm{~g} \mathrm{~kg}^{-1}$ of seed that were diluted with $5 \mathrm{ml}$ of water. The treated seeds were shade dried and evaluated for the seed and seedling quality characters along with control.

\section{0 seed weight $(\mathrm{mg})$}

Eight replicates of hundred seeds were drawn from each treatment, weighed in sensitive electronic balance and expressed in milligrams (ISTA, 1999).

\section{Germination (\%)}

Four replicates of hundred seeds were sown in sand medium and kept under the test conditions of $25^{\circ} \pm$ $1^{\circ} \mathrm{C}$ and $95^{\circ} \pm 3$ per cent relative humidity maintained in a germination room illuminated with fluorescent light. After the test period of seven days the normal seedlings were counted and the mean values expressed as percentage (ISTA, 1999) to the total number of seeds placed for germination.

\section{Root length (cm)}

At the time of germination count, ten normal seedlings were taken at random. The length between the collar and tip of the primary root was measured as root length and the mean length expressed in centimeter.

\section{Shoot length (cm)}

From the ten seedlings used for measuring the root length, the length between collar and tip of the primary shoot was measured as shoot length and the mean value expressed in centimeter.

\section{Drymatter production (mg 10 seedlings $^{-1}$ )}

Ten normal seedlings from the germination test were selected at random, dried in a hot air oven maintained at $85^{\circ} \mathrm{C}$ for $48 \mathrm{~h}$ and cooled in a desiccators for 30 minutes, and weighed in an electronic digital balance. The mean weight was expressed as dry matter production 10 seedlings $^{-1}$ in milligram (Gupta, 1993). 


\section{Vigour index}

The Vigour index values were computed, adopting the procedure of Abdul-Baki and Anderson (1973) as given below and expressed as whole number.

Vigour index $=$ Germination $(\%) \mathrm{x}$ Total seedling length $(\mathrm{cm})$

\section{Electrical conductivity $\left(\mathrm{dSm}^{-1}\right)$}

Four replicates of fifty seeds were taken at random from each treatment, prewashed with deionised water to remove the adhering chemicals and soaked in $50 \mathrm{ml}$ of deionised water for $12 \mathrm{~h}$ at room temperature. The seed steep water was decanted and measured for electrical conductivity in a digital conductivity meter having a cell constant of 1.0. The conductivity values were expressed in decisiemens (Presley, 1958).

\section{Germination after storage $(\%)$}

The seeds invigourated were stored in cloth bag upto a period of 4 months and were evaluated for the germination percentage.

\section{Results and Discussion}

Highly significant results were obtained due to doses of polymer for all the evaluated parameters except for 100 seed weight (Table 1).

Hadas and Russo (1974) found that the polymer coating have high water conductivity and improve the seed water contact area. Seed water contact area expands an hydration which is important in enhancing imbibitions (Collies and Hector, 1996). Seeds, which are rich in starch, imbibe less water slowly when compared to protein rich seeds. Rate and degree of hydration of seeds depend on the nature and amount of its storage material. Hence, hydrophobic polymer is highly suitable for starch rich corn seeds (Baxter and waters.1986 a). In the present study, the seeds coated with polymer @ $4 \mathrm{~g} \mathrm{~kg}^{-1}$ seed has increased the germination to 89 per cent followed by seeds coated with polymer @ $3 \mathrm{~g} \mathrm{~kg}^{-1}$ seed (87 per cent). The other parameters like root length, shoot length, drymatter production and vigour index were also higher in seeds coated with polymer @ $4 \mathrm{~g} \mathrm{~kg}^{-1}$ seed. Dexter and Takoa (1960) also reported that surface coating of seed with hydrophilic collids were extreme in accelerating water uptake from sand and in accelerating emergence under normal conditions in the field. Reduced germination of seed with higher doses of polymer of the present study could be due to the restricted oxygen supply to the enclosed embryo and to the retention or water-soluble germination inhibitors as reported by Xianming duan and Joseph, (1997).

Thus the study expressed that seed coated with polymer @ $4 \mathrm{~g} \mathrm{~kg}^{-1}$ seed improved the seed and seedling quality characters and the treated seed also could be stored well upto 4 months.

\section{References}

[1]. Aravindkumar, R., V. Prakash and R.P. Singh. 1991. Influence of starch polymer on yield attributes, yield and quality of mustard (Brassica Juncea) under field conditions. Indian J. Agron., 36(4): 612-613.

[2]. Baxter, L and L. Waters Jr.1986b.Errect of hydrophilic polymer seed coating on the imbibitions , respiration and germination of sweet corn at four matric potentials. J. Amer.Soc.Hort.Sci.,111(4):517-520

[3]. Chachalis, D. and M.L. Smith. 2001. Hydrophobic polymer application reduces imbiibition rate and partially improves germination of emergence of soybean seedlings. Seed. Sci. \& Technol., 29(1): 91-98.

[4]. Chikkanna, C., S. Thimmegowda, R. Paramesh and N. Devakumar. 1993. Use of hydrophilic polymer on water use efficiency of different crop under rainfed farming. Indian Agriculturist, 37(1): 39-45.

[5]. Prochaske, S. 2001. Emergence of polymer coated soybeans using a very early planting date. Ohio Agril. Res. and Dev. Center, 17(9): 19-20.

[6]. Rana, K.S, Ashok Kermar and R.C Gautan. 2001. Effect of starch polymer (Jalashakthi) on yield attributes, yield and water use efficiency of mustard under rainfed conditions. Crop Res., 22(3): 395-397. 
Influence of polymer coating on seed and seedling quality characteristics

Table l. Influence of polymer coating on seed and seedling quality characteristics

\begin{tabular}{|c|c|c|c|c|c|c|c|c|}
\hline $\begin{array}{c}\text { Polymer } \\
\text { concentration @g } \\
\mathrm{kg}^{-1} \text { seed }\end{array}$ & $\begin{array}{c}100 \\
\text { seed } \\
\text { weight } \\
(\mathrm{mg})\end{array}$ & $\begin{array}{c}\text { Germination } \\
(\%)\end{array}$ & $\begin{array}{l}\text { Root } \\
\text { length } \\
(\mathrm{cm})\end{array}$ & $\begin{array}{l}\text { Shoot } \\
\text { length } \\
(\mathrm{cm})\end{array}$ & $\begin{array}{c}\text { Drymatter } \\
\text { production } \\
10 \text { seedling } \\
(\mathrm{mg})\end{array}$ & $\begin{array}{l}\text { Vigour } \\
\text { index }\end{array}$ & $\begin{array}{l}\text { Electrical } \\
\text { conductivity } \\
\left(\mathrm{dSm}^{-1}\right)\end{array}$ & $\begin{array}{c}\text { Germination } \\
\text { after } 4 \text { months } \\
(\%)\end{array}$ \\
\hline 3 & 305 & $\begin{array}{c}87 \\
(68.87)\end{array}$ & 13.0 & 6.2 & 45.0 & 1670 & 0.13 & $\begin{array}{c}84 \\
(66.42)\end{array}$ \\
\hline $4^{-}$ & $305^{-\cdots-1}$ & $\begin{array}{c}89 \\
(70.63)\end{array}$ & $13.8^{---}$ & $6.3^{--}$ & 49.5 & $1788^{--}$ & $0.10^{-}$ & $\begin{array}{c}86 \\
(68.03)\end{array}$ \\
\hline$-5^{-}$ & 306 & $\begin{array}{c}86 \\
(68.03)\end{array}$ & $12.8^{-1}$ & $6.0^{-}$ & $47.0^{-}$ & $1616^{-}$ & 0.09 & $\begin{array}{c}85 \\
(67.21)\end{array}$ \\
\hline 6 & 307 & $\begin{array}{c}84 \\
(66.42)\end{array}$ & $12.6^{-}$ & $5.9^{-}$ & $40.0^{\circ}$ & $1554^{---}$ & 0.07 & $\begin{array}{c}83 \\
(65.65)\end{array}$ \\
\hline Control & 304 & $\begin{array}{c}80 \\
(63.43)\end{array}$ & $8.10^{-}$ & $5.2^{-1}$ & 37.1 & $1064^{-}$ & $0.08^{-}$ & $\begin{array}{c}75 \\
(60.00)\end{array}$ \\
\hline $\mathrm{CD}(\mathrm{P}=0.05)$ & NS & (1.819) & 1.118 & 1.123 & 1.909 & 1.694 & 0.019 & 1.873 \\
\hline
\end{tabular}

(Figures in parentheses are arc sine transformed values) 